AGNIESZKA IWANICKA

ORCID 0000-0003-1176-6725

Uniwersytet im. Adama Mickiewicza

$w$ Poznaniu

\title{
NOWE TECHNOLOGIE \\ W PRACY NAUCZYCIELA EDUKACJI WCZESNOSZKOLNEJ. RAPORT Z BADAŃ
}

AвSTRACt. Iwanicka Agnieszka, Nowe technologie w pracy nauczyciela edukacji wczesnoszkolnej. Raport $z$ badan [New Technologies in the Work of the Early School Education Teacher. A Study Report]. Studia Edukacyjne nr 54, 2019, Poznań 2019, pp. 283-296. Adam Mickiewicz University Press. ISSN 1233-6688. DOI: 10.14746/se.2019.54.16

The new core curriculum for general education introduced in September 2017 (Journal of Laws 2017, item 356) introduced changes taking into account the use of new technologies in early school education. From now on, the school is to better prepare students for the requirements of a digital society, including a creative use of media. This requires the teacher's readiness to introduce the media into the educational process, commitment to and efficient use of the digital media in individual education. I was wondering about the attitude of early school education teachers to using new technologies in lessons (especially in the context of the new curriculum). Moreover, I wanted to see if teachers show commitment to developing their own digital skills. Such an attitude would be justified: the high digital competences of teachers not only help the proper implementation of the core curriculum in grades $0-3$, but also help in career promotion and prepare children for efficient functioning in a digital society. To answer the above questions, I carried out my own diagnostic survey on a group of 460 early school education teachers $(\mathrm{N}=460)$, using a questionnaire.

Teachers indicated a diverse attitude to both the changes introduced in the core curriculum and the use of digital media in education. They mainly point to their own digital incompetence in the use of new technologies in early school education lessons. New media are most often used in lessons by teachers older in terms of age and work experience; we can associate it with teachers' professional promotion, which is connected with the requirement of using multimedia in the learning process as defined by the legislator. Teachers do not rate their digital skills too highly yet at the same time show interest in courses, trainings and workshops organized by the school, thanks to which they can improve their skills in this area. They also recognize that a digitally competent teacher is the answer to the needs of a new, modern school.

Key words: digital media, digital competences, early education 


\section{Wprowadzenie}

Współczesna rzeczywistość podlega ciągłym przemianom społecznym, kulturowym oraz technologicznym, które nie pozostają bez wpływu na szkołę. Od nauczycieli wymaga się nie tylko gotowości do sprawnego reagowania na zachodzące zmiany i niestabilność edukacyjną, ale także wysoko rozwiniętych umiejętności dydaktycznych - uwzględniających również umiejętne korzystanie z nowych technologii. Jedną z konsekwencji aktywności i podejmowanych przez człowieka inicjatyw oraz realizowanej w sposób zamierzony i niezamierzony edukacji medialnej są kompetencje medialne - o indywidualnym dla każdego człowieka, zróżnicowanym poziomie. O potrzebie nabywania takich kompetencji przekonane są nie tylko instytucje rządowe, organizując ogólnopolskie projekty i programy (np. program Cyfrowa Szkoła, NASK), włączając edukację medialną do strategii rozwoju państwa polskiego, pozarządowe ${ }^{1}$, ośrodki naukowe i towarzystwa, ale i Komisja Europejska, która wydała szereg zaleceń odnośnie kształtowania kompetencji medialnych społeczeństwa ${ }^{2}$. Zalecenia te sprowadzają się między innymi do kształtowania kompetencji medialnych i cyfrowych przez szkoły oraz uznania ich za część kompetencji kluczowych w społeczeństwie informacyjno-komunikacyjnym. Umiejętności nabyte $\mathrm{w}$ domu, zgodnie z unijnymi dyrektywami, powinny być dalej rozwijane $\mathrm{w}$ środowisku szkolnym i w trakcie uczenia się przez całe życie oraz wzmacniane za pomocą działań organów krajowych, rządowych i regulacyjnych, jak też działań sektora medialnego. Eksperci z Komisji rozumieją kompetencje medialne za połączenie kompetencji indywidualnych z jednej strony oraz czynników środowiskowych z drugiej³. Aby zrealizować zalecenia Komisji Europejskiej, potrzebni są kompetentni cyfrowo nauczyciele, którzy swoją wiedzą, umiejętnościami oraz postawami będą wspomagać dzieci i młodzież w kształtowaniu przez nich odpowiednich kompetencji. Badania pokazują, że dzieci przychodząc do szkoły, nie potrafią w sposób wartościowy korzystać z nowych technologii ${ }^{4}$. Ich umiejętności ograniczają się do obsługi

${ }^{1}$ A. Iwanicka, N. Walter, A. Kiełkiewicz-Janowiak, Media and Information Literacy Policies in Poland (2013), ANR TRANSLIT and COST „TransformingAudiences/Transforming Societies”, 2014.

${ }^{2}$ E. Murawska-Najmiec, Organizacje międzynarodowe: Edukacja medialna w polityce Unii Europejskiej i Unesco, [w:] Cyfrowa Przyszłość, 2016 https:/ / nowoczesnapolska.org.pl/wp-content/ uploads/2012/01/Cyfrowa-Przysz\%C5\%82o\%C5\%9B\%C4\%87-rozdzia\%C5\%82-06.pdf

${ }^{3}$ A. Ogonowska, G. Ptaszek, Edukacja medialna w dobie wspótczesnych zmian kulturowych, społecznych i technologicznych, Kraków 2015, s. 9.

${ }^{4}$ D. Batorski, Technologie i media w domach i życiu Polaków, [w:] Diagnoza społeczna 2015: Warunki i jakość życia Polaków, red. J. Czapiński, T. Panek, Warszawa 2015; J. Pyżalski, Dzieci w wieku przedszkolnym w świecie technologii informacyjno-komunikacyjnych - w stronę zagrożeń, [w:] Małe 
urządzeń cyfrowych, włączenia bajki, filmu lub gry. Nie wiedzą, że media cyfrowe mogą służyć do innych niż rozrywka celów: do nauki, pracy zespołowej, rozwoju kreatywności, twórczości, pasji i zainteresowań. Ponieważ domowa edukacja medialna wciąż jeszcze stoi na niskim poziomie, to w dużej mierze od szkoły i nauczycieli zależy, jakie doświadczenia cyfrowe zdobędą dzieci, czego się nauczą i jakie nawyki cyfrowe posiądą.

Mając na uwadze powyższe, zasadne wydało mi się sprawdzenie, jaki stosunek przejawiają nauczyciele edukacji wczesnoszkolnej do wykorzystywania nowych technologii na swoich lekcjach? Czy wykazują się zaangażowaniem w zakresie nabywania i rozwijania własnych kompetencji cyfrowych po to, aby z jednej strony - realizować założenia nowej podstawy programowej, z drugiej - przyczynić się do nabywania kompetencji cyfrowych przez dzieci. Mimo wprowadzonej w 2017 roku nowej podstawy programowej kształcenia ogólnego dla szkół podstawowych, która nakłada na nauczycieli obowiązek wprowadzenia treści okołoinformatycznych, wciąż niewiele istnieje badań, z których moglibyśmy się dowiedzieć, jaką postawę wobec tego zagadnienia wykazują nauczyciele edukacji wczesnoszkolnej. Moje badania są próbą uzupełnienia luki na tym polu badawczym.

\section{Media cyfrowe i treści informatyczne w edukacji wczesnoszkolnej}

Polskie szkoły są coraz lepiej wyposażone cyfrowo, jednak nie zawsze nauczyciele edukacji wczesnoszkolnej wykazują chęci, aby wykorzystywać je (jako środki dydaktyczne) w procesie kształcenia. Powodem są najczęściej cechy indywidualne nauczyciela, jak i brak wiary w efektywność nauczania wspartego mediami ${ }^{5}$. Nauczyciele co prawda deklarują wykorzystywanie mediów cyfrowych na lekcjach, ale rozumieją przez to głównie wspieranie się prezentacjami multimedialnymi, które nie angażują uczniów w jakąkolwiek aktywność i sprawiają, że lekcje nadal prowadzone są tokiem podającym ${ }^{6}$. To, czy nauczyciele włączą media do swoich edukacji ma też bezpośredni związek z ich wiekiem, przekonaniami i wątpliwościami, jakie mają na temat obecności mediów cyfrowych w szkole. Według Hoskins i Sakamoto, zdecydowanie chętniej TIK na lekcjach używają nauczyciele urodzeni już jako

dzieci w świecie technologii informacyjno-komunikacyjnych. Pomiędzy utopijnymi szansami a przesadzonymi nadziejami, red. J. Pyżalski, Łódź 2017, s. 160-163.

${ }_{5}$ Polskaszkoławdobiecyfryzacji.Diagnoza2017,red.M.Plebańska,https:// onedrive.live.com/ ?authkey $=\% 21$ AOQ4UX8Db5IZqrw\&cid=3D4AC758B37A833C\&id=3D4AC758B37A833 C\%21108\&parId=root\&action=locate, , [data dostępu: 10.06.2019], s. 7-24.

${ }^{6}$ Tamże, s. 24. 
cyfrowi tubylcy, zarazem młodzi stażem, którzy dodatkowo są przeświadczeni o swoich wysokich cyfrowych kompetencjach ${ }^{7}$. Nie jestem jednak pewna, czy tak jest rzeczywiście, bowiem najnowsze badania pokazują, że młode pokolenie wcale nie ma wysokich kompetencji cyfrowych, nie wykazuje się też aktywnością cyfrową, a ich działania są w dużej mierze odtwórcze i pozbawione większej wartości ${ }^{8}$. A zatem, wiek wcale nie musi być wyznacznikiem używania przez nauczycieli nowych technologii na lekcjach i wykazywania się chęcią rozwijania własnych kompetencji cyfrowych.

Sama dostępność nowych technologii w szkole nie jest też równoznaczna z ich wykorzystywaniem przez nauczyciela, ponieważ ci, którzy nie czują się komfortowo w obecności mediów cyfrowych, lub czują się wręcz przymuszani do ich używania, mogą mieć odczucie, że są zbędni w klasie szkolnej. Często ten problem znika po przejściu odpowiedniego szkolenia, które zwiększa poczucie kompetencji w zakresie użytkowania nowych technologii. Nauczyciele dużo chętniej korzystają też z nowych technologii w klasach starszych, gdzie młodzież wykazuje się większym poziomem samodzielności, a kompetencjami cyfrowymi nierzadko ich przewyższa, niż w nauczaniu wczesnoszkolnym, które wymaga większych kompetencji i zaangażowania nauczyciela. Tymczasem, nowa podstawa programowa kształcenia ogólnego dla szkoły podstawowej ${ }^{9}$ nakłada na nauczycieli już od pierwszych klas obowiązek wdrażania nowych technologii, w tym realizowania treści okołoinformatycznych, do wszystkich edukacji.

Ponadto, ustawodawca założył, że każdy nauczyciel ubiegający się o kolejny stopień awansu zawodowego (nauczyciel kontraktowy, mianowany, dyplomowany) lub ocenę pracy powinien wykazywać się znajomością narzędzi multimedialnych i informatycznych oraz umiejętnością wykorzystywania ich zgodnie ze specyfiką prowadzonych przez siebie lekcji. Ocenie poddawane jest planowanie, organizowanie i prowadzenie zajęć dydaktycznych, wychowawczych i opiekuńczych wynikających ze specyfiki szkoły i zajmowanego stanowiska, z wykorzystaniem metod aktywizujących ucznia - w tym narzędzi multimedialnych i informatycznych właśnie ${ }^{10}$. Komisja egzaminacyjna oprócz standardowej procedury egzaminacyjnej może poprosić kandydata, aby zaproponował rozwiązanie wskazanego przez ko-

7 B. Hoskins Sakamoto B., The role of technology in early years language education, [w:] Early Second Language Education: International perspectives of theory and practice, red. S. Mourao, M. Lourenco, New York 2015, s. 245.

${ }^{8}$ J. Pyżalski i in., Polskie badania EU Kids Online 2018, Poznań 2019; tenże i in., Pozytywny internet i jego młodzi twórcy. Dobre i złe wiadomości z badań jakościowych, NASK 2019; M. Tanaś, Raport z Badania Nastolatki 3.0. NASK, Warszawa 2017.

9 Rozporządzenie MEN z 14 lutego 2017 r., w sprawie Podstawy Programowej Kształcenia Ogólnego dla Szkół Podstawowych, DzU 2017 poz. 356.

${ }^{10}$ Tamże, poz. 1574. 
misję problemu łączącego się z wykonywaną pracą, uwzględniając nie tylko praktykę szkolną i przepisy prawa, ale też używając narzędzi cyfrowych ${ }^{11}$. A zatem, podnoszenie kompetencji cyfrowych wydaje się priorytetem dla nauczycieli dbających o rozwój nie tylko własny, ale i podopiecznych.

Wprowadzona do szkół w 2017 roku podstawa programowa ustanawia między innymi takie cele, jak: rozwijanie kreatywności, umiejętności krytycznego i logicznego myślenia, rozumowania, argumentowania i wnioskowania, rozbudzanie ciekawości poznawczej uczniów oraz motywacji do nauki. Cele te idealnie wpisują się w myśl kształcenia multimedialnego z udziałem nowych technologii i szeroko rozumianej edukacji medialnej oraz kształtowania umiejętności poprzez działanie ${ }^{12} \mathrm{z}$ wykorzystaniem nie tylko mediów tradycyjnych (tzw. starych), ale i nowych mediów (multimediów), ze szczególnym uwzględnieniem komputerów z dostępem do Internetu (i jego usługami, tzw. nowymi nowymi mediam $i^{13}$ oraz programami do wczesnej nauki kodowania), tablic interaktywnych, smartfonów (z zainstalowanymi aplikacjami), interaktywnych, programowalnych robotów $\mathrm{i}$ innych nowych technologii.

Wymienione $\mathrm{w}$ podstawie programowej cele mają odniesienie nie tylko do samego procesu kształcenia, ale i szerzej - do całego społeczeństwa, bowiem odpowiadają na potrzeby rynku pracy: mają przygotować do abstrakcyjnego i logicznego myślenia, nauczyć rozwiązywania problemów i myślenia komputacyjnego (rozumianego jako proces znajdowania rozwiązań wobec pewnych otwartych problemów), które jest nierozerwalnie związane z programowaniem, a którego elementy nauczyciel ma wprowadzać do poszczególnych edukacji za pomocą nowych narzędzi. Do obowiązków nauczyciela powinno zatem należeć wprowadzanie nowych technologii do edukacji, angażowanie uczniów w aktywne i twórcze ich wykorzystywanie oraz tworzenie cyfrowych treści, jak też aranżowanie takich sytuacji z udziałem mediów, które będą nawiązywały do realnych problemów i rzeczywistych sytuacji. Szkoła ma przygotować do kreatywnego korzystania $\mathrm{z}$ mediów:

(...) stwarzać uczniom warunki do nabywania wiedzy i umiejętności potrzebnych do rozwiązywania problemów z wykorzystaniem metod i technik wywodzących się z informatyki, w tym logicznego i algorytmicznego myślenia, programowania, posługiwania się aplikacjami komputerowymi, wyszukiwania i wykorzystywania informacji z różnych źródeł, posługiwania się komputerem i podstawowymi urządzeniami cyfrowymi oraz stosowania tych umiejętności na zajęciach z różnych

${ }^{11}$ Rozporządzenie MEN z 26 lipca 2018 r. w sprawie uzyskiwania stopni awansu zawodowego przez nauczycieli, $\$ 12$, ust. 1 .

${ }_{12}$ J. Bednarek, Multimedia w ksztatceniu, Warszawa 2012, s. 86.

${ }^{13}$ P. Levinson, Nowe nowe media, Kraków 2010, s. 11-14. 
przedmiotów m.in. do pracy nad tekstem, wykonywania obliczeń, przetwarzania informacji i jej prezentacji w różnych postaciach. Szkoła ma również przygotowywać ich do dokonywania świadomych i odpowiedzialnych wyborów w trakcie korzystania z zasobów dostępnych w internecie, krytycznej analizy informacji, bezpiecznego poruszania się $\mathrm{w}$ przestrzeni cyfrowej, w tym nawiązywania i utrzymywania opartych na wzajemnym szacunku relacji z innymi użytkownikami sieci ${ }^{14}$.

Duża część wprowadzonych do podstawy programowej zmian związana jest $\mathrm{z}$ osiągnięciami ucznia $\mathrm{w}$ zakresie programowania i rozwiązywania problemów z wykorzystaniem komputera oraz innych urządzeń cyfrowych i dotyczy takich aktywności, jak: posługiwanie się komputerem do wykonania zadania, programowanie wizualne, tworzenie komputerowych komunikatów graficznych, korzystanie z zasobów internetowych. Dzieci z klas 0-3 powinny programować wizualnie proste historyjki, umieć wykonać pojedyncze polecenia $\mathrm{w}$ programie do kodowania. $\mathrm{W}$ początkowej fazie sugeruje się rozpoczynanie działań z wykorzystaniem przestrzeni klasy i organizowanie aktywności dzieci z wykorzystaniem liczmanów, gier planszowych i tym podobnych, a więc nie zawsze korzystając z komputerów po to, aby dzieci poznawały wybrane pojęcia $\mathrm{w}$ formie zabawy. Stopniowo treści informatyczne mają być wdrażane we wszystkich edukacjach z wykorzystaniem narzędzi TIK $^{15}$ tak, aby z czasem tworzyć proste programy sterujące robotami edukacyjnymi lub postaciami na ekranie monitora, posługiwać się komputerem z różnymi aplikacjami i co najważniejsze - wykorzystywać poznane umiejętności do nauki czytania, pisania i rachowania.

Tym samym, to obowiązkiem nauczyciela edukacji wczesnoszkolnej jest aranżowanie aktywności związanych z wykorzystaniem mediów cyfrowych i kształtowanie kompetencji cyfrowych dzieci. Czy jednak nauczyciele są przygotowani do takich działań? Obowiązujące programy studiów z zakresu edukacji wczesnoszkolnej w przeważającej większości nie przewidują zajęć tak z nauki kodowania, jak i podejmowania innych aktywności z wykorzystaniem nowych technologii (np. obsługi robotów edukacyjnych), a zatem nawet najmłodsi nauczyciele - będący już przedstawicielami pokolenia cyfrowych tubylców - nie otrzymują niezbędnego przygotowania, aby podejmować takie działania. Tymczasem, to od ich zaangażowanej postawy zależy, czy dzieci będą doskonaliły swoje kompetencje cyfrowe przy ich udziale, czy nie.

Aktywność cyfrowa nauczyciela edukacji wczesnoszkolnej jest zatem uwarunkowana wieloma czynnikami, które możemy określić jako: 1) cechy indywidualne nauczyciela; 2) poziom jego kompetencji cyfrowych; 3) motywacja we-

${ }^{14}$ Rozporządzenie MEN z 14 lutego 2017 r., w sprawie Podstawy Programowej Kształcenia Ogólnego dla Szkół Podstawowych, DzU 2017 poz. 356, s. 3.

15 Tamże, s. 47. 
wnętrzna zwiększania kompetencji cyfrowych (chęć rozwoju i samokształcenie w zakresie umiejętności cyfrowych); 4) motywacja zewnętrzna zwiększania kompetencji cyfrowych (awans zawodowy, realizowanie podstawy programowej); 5) wsparcie szkoły w zakresie podnoszenia kompetencji cyfrowych (kursy, szkolenia, warsztaty); 6) wyposażenie w nowe technologie szkoły.

\section{Badania własne - procedura i wyniki}

Aby dowiedzieć się więcej na temat stosunku nauczycieli edukacji wczesnoszkolnej do wykorzystywania nowych technologii na lekcjach oraz ich zaangażowania $\mathrm{w}$ nabywanie i rozwijanie własnych kompetencji cyfrowych, zaprojektowałam badania sondażowe, które zostały zrealizowane w styczniu 2019 roku wśród 460 nauczycieli klas 0-3 szkoły podstawowej $(\mathrm{N}=460)$. W badaniu wzięli udział nauczyciele z różnych województw Polski - 440 kobiet i 20 mężczyzn. Najwięcej nauczycieli, bo aż 61\% miało długi staż pracy - 20 i więcej lat, pozostali pracowali w szkole 15 lat (12\%) i krócej. Aż 91\% ankietowanych to pracownicy szkoły państwowej, pozostałe osoby zatrudnione były w szkole prywatnej lub społecznej. Techniką badawczą, którą się posłużyłam była ankieta online. Kwestionariusz zawierał 25 pytań, które miały formę zamkniętą z kategoriami do wyboru, skalą, rangami oraz elementami otwartymi. Celem badania było poznanie opinii nauczycieli na temat wykorzystywania przez nich nowych technologii w klasach 0-3 oraz poznanie ich deklaracji związanych z zaangażowaniem $w$ rozwój własnych kompetencji cyfrowych. Wyodrębniono zatem następujące problemy badawcze ${ }^{16}:$ 1) Jaki stosunek przejawiają nauczyciele edukacji wczesnoszkolnej do korzystania z nowych technologii na lekcjach? 2) Czy nauczyciele wykazują się zaangażowaniem w zakresie rozwijania własnych kompetencji cyfrowych?

\section{Stosunek nauczycieli edukacji wczesnoszkolnej do korzystania z nowych technologii na lekcjach}

Przebadana przeze mnie grupa nauczycieli edukacji wczesnoszkolnej prezentuje zróżnicowany stosunek zarówno do wprowadzonych w podstawie programowej zmian, jak i samego wykorzystywania mediów cyfrowych w edukacji. Mimo iż 73\% ankietowanych deklaruje, że dokonane ustawowo zmiany (w tym obecność programowania w edukacji elementarnej) są po-

${ }^{16}$ Na potrzeby niniejszego opracowania wykorzystano wyniki badań ankietowych odnoszące się tylko do wybranych problemów badawczych 
trzebne, to jednak $14 \%$ badanych twierdzi, że nie jest przekonana do tej decyzji, za powód wskazując głównie swoją niekompetencję (13\%) w zakresie wykorzystywania nowych mediów. Wśród ankietowanych pojawiły się też głosy o niechęci wobec wprowadzonych zmian (3\% badanych).

Pytani, jak często używają poszczególnych nowych technologii na lekcjach, nauczyciele wskazywali komputer $z$ dostępem do Internetu jako najbardziej popularne medium, z którego korzystają przynajmniej raz w tygodniu (59\%), w tym do prezentowania treści w programie Power Point z wykorzystaniem projektora (27\% przynajmniej raz w miesiącu). Coraz częściej szkoły wyposażone są $\mathrm{w}$ tablice interaktywne $-42 \%$ moich ankietowanych odpowiedziało, że korzysta $\mathrm{z}$ nich przynajmniej raz w tygodniu, ale aż $20 \%$ nie ma ich na wyposażeniu szkoły bądź z nich nie korzysta. Zapytałam także nauczycieli, czy i jak często wykorzystują na swoich zajęciach edukacyjnych (sugerowane w nowej podstawie programowej) programy do nauki kodowania oraz roboty edukacyjne, które sprawiają, że uczniowie wykazują się większą aktywnością na lekcjach, pracują bardziej kreatywnie, czy uczą się rozwiązywania problemów.

Tabela 1

Korzystanie z programów do kodowania i robotów edukacyjnych na lekcjach

\begin{tabular}{|c|c|c|c|}
\hline \multicolumn{2}{|c|}{$\begin{array}{l}\text { Korzystanie z programów do kodowania } \\
\text { i robotów edukacyjnych na lekcjach }\end{array}$} & $\begin{array}{c}\text { Liczba } \\
\text { wskazań }\end{array}$ & $\begin{array}{c}\% \\
N=460\end{array}$ \\
\hline \multirow{5}{*}{$\begin{array}{l}\text { Korzystanie } \\
\text { z programów } \\
\text { do kodowania }\end{array}$} & nie używam & 156 & 34 \\
\hline & $\begin{array}{l}\text { używam bardzo rzadko - parę razy } \\
\text { w roku }\end{array}$ & 32 & 7 \\
\hline & $\begin{array}{l}\text { używam sporadycznie - rzadziej niż raz } \\
\text { w miesiącu }\end{array}$ & 120 & 26 \\
\hline & często - parę razy w miesiącu & 108 & 23 \\
\hline & $\begin{array}{l}\text { bardzo często - przynajmniej raz w tygo- } \\
\text { dniu }\end{array}$ & 44 & 10 \\
\hline \multirow{5}{*}{$\begin{array}{l}\text { Korzystanie } \\
\text { z robotów } \\
\text { edukacyjnych }\end{array}$} & nie używam & 276 & 60 \\
\hline & $\begin{array}{l}\text { używam bardzo rzadko - parę razy } \\
\text { w roku }\end{array}$ & 76 & 16 \\
\hline & $\begin{array}{l}\text { używam sporadycznie, rzadziej niż raz } \\
\text { w miesiącu }\end{array}$ & 40 & 9 \\
\hline & często - parę razy w miesiącu & 44 & 10 \\
\hline & $\begin{array}{l}\text { bardzo często - przynajmniej raz w mie- } \\
\text { siącu }\end{array}$ & 24 & 5 \\
\hline
\end{tabular}

Źródło: opracowanie własne. 
Na podstawie danych zebranych w tabeli 1 można stwierdzić, że zarówno kodowanie, jak i programowanie zaczyna cieszyć się popularnością wśród nauczycieli; jest używane coraz częściej i chętniej. Wciąż jednak istnieje liczna grupa (34\% jeśli chodzi o kodowanie i aż $60 \%$ w wypadku robotów edukacyjnych), która nie korzysta z tego rodzaju rozwiązań edukacyjnych. Zapytani, dlaczego wciąż tak rzadko korzystają z tego rozwiązania edukacyjnego, nauczyciele odpowiadają, że nie mają pomysłu, jak wprowadzić naukę kodowania do swoich edukacji (32\%), boją się też, że ich kompetencje są niewystarczające $(26 \%)$, nie mają wystarczającej ilości sprzętu (24\%) lub po prostu - nie są przekonani do tego rozwiązania edukacyjnego (18\%).

Najchętniej nowe technologie wykorzystują na lekcjach nauczyciele powyżej 40. roku życia (51\%). Można to wiązać z ich awansem zawodowym (najczęściej na stopień nauczyciela dyplomowanego), który łączy się ze wspomnianym już wymogiem wykorzystywania multimediów w procesie uczenia. Młodsze osoby, na przykład te bezpośrednio po studiach, mimo przypisywanej im przynależności do pokolenia cyfrowych tubylców $\mathrm{w}$ dużo mniejszym stopniu korzystają z mediów na lekcjach (w moich badaniach tylko $25 \%$ nauczycieli w przedziale wiekowym 25-30 lat). Wynika to być może $\mathrm{z}$ ich zaaferowania nową sytuacją zawodową (pierwsza praca), stawiania na tradycyjne metody, które stoją $\mathrm{w}$ opozycji do dominujących $\mathrm{w}$ codziennym życiu dzieci nowych technologii i próbą osiągania założonych celów bez korzystania z tego typu środków dydaktycznych.

Nauczyciele prezentują zróżnicowane postawy wobec programowania wizualnego - od zainteresowania (wybrane odpowiedzi z pytania otwartego): Na pewno trzeba uczyć dzieci programowania; Zastanawiam się, jaki program wybrać, aby zaciekawił dzieci; Programowanie pomoże moim wychowankom w przyszłości; Jestem ciekawa, jakie daje możliwości; Chcę tego doświadczyć; wręcz podekscytowania: Dzieciaki uwielbiaja programować, ciesze się na te lekcje tak, jak oni; Zawsze zastanawiam się, czym dzieci mnie zaskocza tym razem; Jestem bardzo ciekawa ich pomystów; Programowanie to dla nas świetna zabawa; Czuję, że sama chciałabym się tym bardziej pobawić; Uwielbiam nowe rozwiązania, które ułatwiaja dzieciakom naukę; po niechęć, obawy i bezradność związaną z odczuwanym brakiem kompetencji: Ogarnia mnie panika, kiedy myśle o programowaniu; Nie mam pojecia, jak się do tego zabrać; Te programy to nic ciekawego; Przeraża mnie myśl, że będę miata to wprowadzić; Zaczna się pytania, a ja nie będę umiała odpowiedzieć; Uważam, że to tylko strata czasu.

Część ankietowanych dostrzega potrzebę nauki programowania już od pierwszej klasy, ale tylko na wyznaczonej do tego edukacji informatycznej (32\%). Inni zgadzają się, że powinno być ono włączane w tok poszczególnych edukacji, ale tylko na zasadzie uatrakcyjnienia lekcji (36\%). Jeszcze inni nie widzą żadnego uzasadnienia dla programowania i „zabawy robotami” (17\%) 
lub nie używają ich z powodu niskiego poczucia kompetencji w tym zakresie $(15 \%)$, pozostali nie mają zdania $\mathrm{w}$ tym temacie $(15 \%)$.

Jeszcze ostrożniej ankietowani wypowiadali się w wypadku korzystania z robotów edukacyjnych: Boję się, bo ich nie znam; Czuję strach, kiedy o nich myślę; A co jak się zepsują? Każdy będzie chciat je wprawić w ruch!; Nie widzę konieczności ich używania; To zwykłe zabawki, a nie nauka; Kiedy ja znajdę czas na nauke czytania i pisania; Nie dam rady, mam za mała wiedzę. Choć zdarzały się i wypowiedzi entuzjastyczne: Super zabawa - uczymy sie, nawet o tym nie wiedzac!; Wspaniała nauka przez zabawę, wyrównuja też szanse edukacyjne; Potrafiq skraść dziecięce serca; Ucza współdziałania w grupie; Lekcje są mega ciekawe z nimi. Niektóre odpowiedzi wskazywały też na wyraźną chęć podniesienia swoich umiejętności i w tym zakresie: Wiem, że musze sie jeszcze dużo nauczyć, ale dam radę!; Wtaśnie kupujemy nowe roboty, muszę się koniecznie podszkolić; Wiem, że potrzebuję szkolenia z ich używania.

Sceptycyzm wykazują też nauczyciele, jeśli chodzi o wykorzystywanie na lekcjach smartfonów - w dalszym ciągu narzędzie to postrzegane jest jako mało przydatne w edukacji. Aż 60 \% nauczycieli nie używa go na lekcjach w ogóle, 11\% deklaruje używanie go parę razy do roku, 12\% średnio raz w miesiącu, 3\% parę razy w miesiącu i $6 \%$ przynajmniej raz w tygodniu. Smartfon, mimo że jest urządzeniem dostępnym i najbardziej lubianym przez dzieci, o szerokim zastosowaniu edukacyjnym - również na poziomie kształcenia wczesnoszkolnego - wciąż traktowany jest dość nieufnie przez nauczycieli.

Zebrane przeze mnie opinie są zbieżne $\mathrm{w}$ wielu aspektach $\mathrm{z}$ badaniami kompetencji komputerowych ICILS, z których wynika, że dwie trzecie ankietowanych nauczycieli nie postrzega nowych technologii i korzystania z nich jako priorytetu, uzasadniając, że nie wprowadzają ich do procesu kształcenia $\mathrm{z}$ powodu braku czasu i kompetencji ${ }^{17}$. Opinie nauczycieli $\mathrm{w}$ tej kwestii są na tyle ważne, że niezbędne wręcz wydaje się przeprowadzenie rzetelnych badań na temat ich szeroko rozumianych kompetencji cyfrowych i nastrojów w dwa lata po przeprowadzonej reformie programowej, która nakłada na nauczycieli obowiązek wprowadzania TIK do procesu uczenia się dzieci.

\section{Zaangażowanie się nauczycieli w podnoszenie własnych kompetencji cyfrowych}

W pierwszej kolejności sprawdziłam, jak badani oceniają swoje kompetencje w zakresie podstawowych umiejętności związanych z obsługą nowych

${ }_{17}$ Raport ICILS, 2013, http://eduentuzjasci.pl/ude/25-informacje/wydarzenia/1136-wyniki-miedzynarodowego-badania-kompetencji-komputerowych-i-informacyjnych-icils.html, [data dostępu: 15.06.2019]. 
technologii. Przebadana grupa nauczycieli najbardziej kompetentnie czuje się w zakresie obsługi komputera z oprogramowaniem edukacyjnym. Swoje umiejętności na bardzo dobre ocenia aż $47 \%$ ankietowanych. Podobnie wysoko oceniają własną umiejętność obsługi projektora multimedialnego i tabletu (46\%). 35\% badanych czuje się bardzo kompetentnie jeśli chodzi o obsługę tablicy interaktywnej, 19\% ocenia tę umiejętność jako dobrą. Zdecydowanie gorzej nauczyciele oceniają swoje umiejętności w zakresie obsługi programów do kodowania.

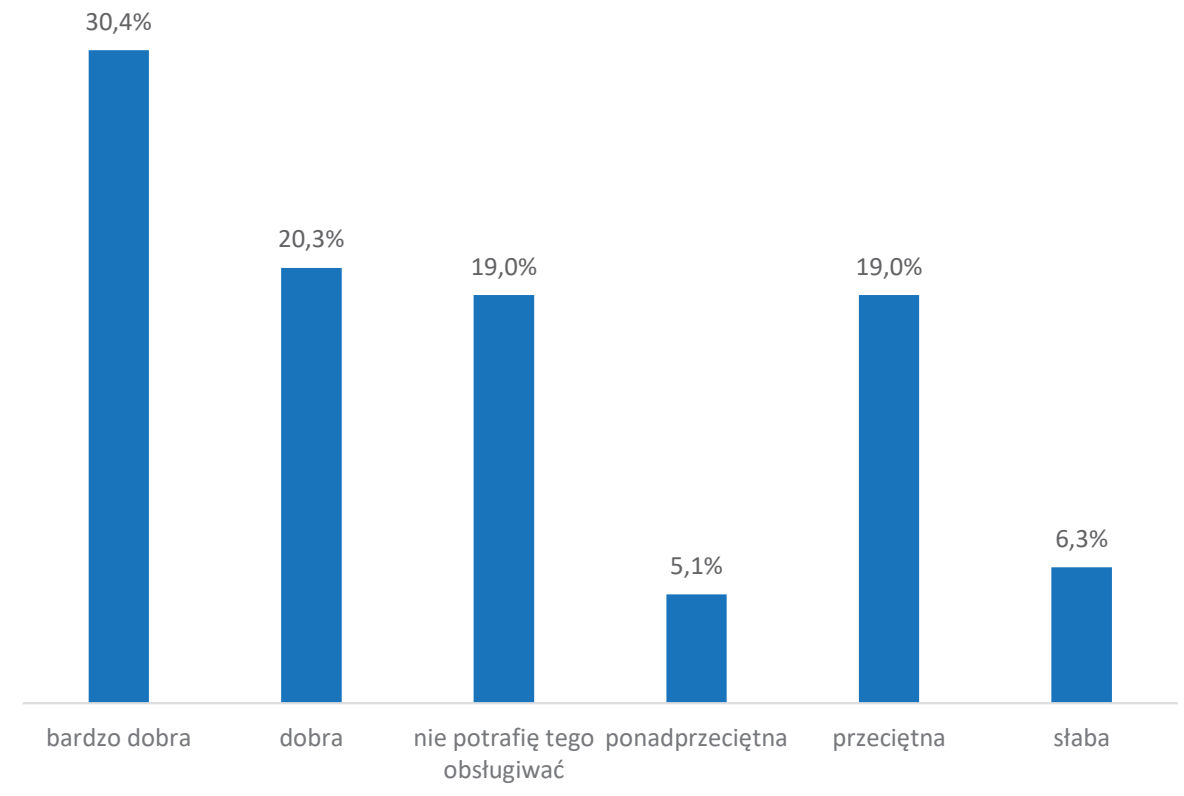

Ryc. 1. Postrzeganie własnych kompetencji w zakresie obsługi programów do kodowania (źródło: opracowanie własne)

Jeszcze słabiej postrzegają umiejętność obsługi robotów edukacyjnych; $45 \%$ ankietowanych deklaruje, że nie umie ich obsługiwać lub posiada umiejętność opanowaną w stopniu słabym (11\%) lub przeciętnym (10\%). Większość z nich dostrzega swoje braki: tylko 14\% swobodnie korzysta ze wszystkich nowych technologii; $51 \%$ dobrze się czuje, korzystając tylko z wybranych technologii; 35\% nie czuje się kompetentnie, kiedy ma wykorzystać nowe technologie na swoich lekcjach.

Nauczyciele nie pozostają jednak bez wsparcia: $w$ ramach podnoszenia kwalifikacji i zwiększania kompetencji uruchamiane są dla nich warsztaty, szkolenia i kursy z podstaw programowania oraz korzystania z narzędzi TIK. 


\section{Czy szkoła wspiera Cię w podnoszeniu kompetencji cyfrowych?}

inna odpowiedź
nie, ale przekonuję dyrekcję do wprowadzenia
technologii do szkoły
tak, ale nie jestem zainteresowany takimi szkoleniami
tak, szkoła bierze udział w programach edukacyjnych
(np. pozarządowych) związanych z edukacją...
tak, w szkole organizowane są szkolenia i warsztaty
dla nauczycieli
tak, szkoła umożliwia nam szkolenia e-learningowe
nie, szkoła nie organizuje ani nie wysyła nas na
szkolenia z tego zakresu
tak, w szkole mogę zawsze liczyć na wsparcie osób
kompetentnych, np. informatyka, matematyka itp.
tak, szkoła wysyła mnie na wybrane szkolenia i
warsztaty
tak, w szkole organizowane są szkolenia i warsztaty
dla nauczycieli
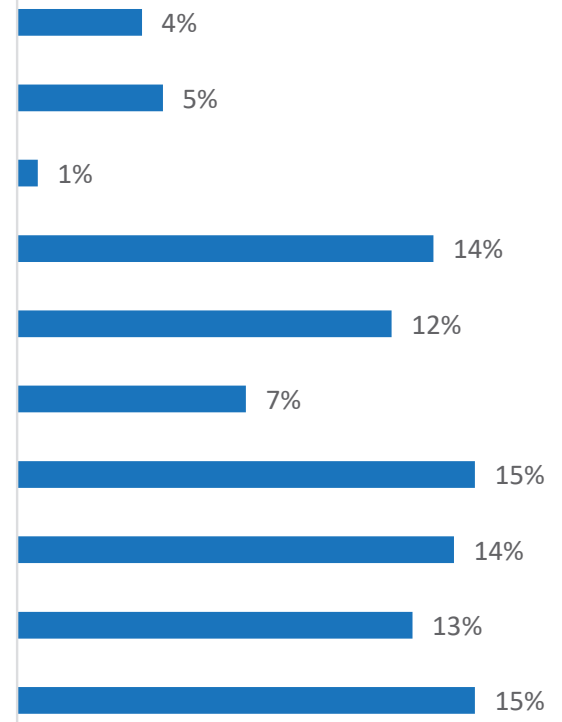

Ryc. 2. Wsparcie szkoły w zakresie uzupełniania nauczycielskich kompetencji cyfrowych (źródło: opracowanie własne)

Oferta szkoleń jest bardzo bogata: oprócz tych najbardziej popularnych z programowania wizualnego w języku Scratch Junior, coraz częściej można nauczyć się wykorzystywać na lekcjach proste edukacyjne roboty typu Ozobot lub dowiedzieć się, jak uczyć za pomocą klocków Lego WeDo 2.0 lub Scottie Go!

Ze wsparcia oferowanego przez szkołę korzysta ponad połowa badanych nauczycieli (54\%), 27\% podnosi swoje kompetencje cyfrowe na własną rękę, 19\% badanych nie jest zainteresowanych żadną formą podnoszenia własnych kompetencji cyfrowych. Nauczyciele chcą rozwijać swoje kompetencje cyfrowe, dostrzegając równocześnie, że pomaga to dzieciom nabywać ważne kompetencje przyszłości (54\%). 35\% badanych deklaruje, że ich własny rozwój kompetencji cyfrowych ma związek z planami zawodowymi (awans) czy zapisami w nowej podstawie programowej (31\%). Jeszcze więcej badanych rozwija swoje kompetencje cyfrowe, aby uatrakcyjnić własne zajęcia $(45 \%)$ lub po prostu nabyć nowe, potrzebne w nowoczesnej szkole umiejętności (59\%) (odpowiedzi nie sumowały się do 100). 


\section{Kompetencje cyfrowe nauczyciela a nowoczesna szkoła - zakończenie}

Zaprezentowany w niniejszym artykule fragment badań oraz rekonstrukcje teoretyczne dotyczące rozwoju kompetencji cyfrowych nauczycieli, jak też zmian wprowadzonych $\mathrm{w}$ podstawie programowej (dotyczących edukacji medialnej i okołoinformatycznej), skłaniają do następujących wniosków.

Dzięki nowej podstawie programowej stoimy przed olbrzymią szansą wprowadzenia pożądanych zmian w szkolnictwie, zniwelowania poszerzającej się luki między pokoleniem urodzonych w cyfrowej rzeczywistości a broniącej się przed nowymi technologiami szkołą. Technologie informacyjno-komunikacyjne wprowadzane do szkół mają szansę sprawić, że dziecko poczuje się w tym środowisku swobodnie i znajomo. Przygotują dzieci do cyfrowej dorosłości poprzez udostępnienie im nowoczesnych narzędzi i wyposażenie w pożądane kompetencje przyszłości. Programowanie bez komputera, maty, plansze, nauka kodowania przez zabawę i ruch, z wykorzystaniem przedmiotów codziennego użytku, roboty edukacyjne, programowalne klocki, zwiększanie motywacji ucznia w przyswajaniu nowych treści przedmiotowych poprzez włączanie $w$ tok lekcji nowych technologii - oto jak mogą przebiegać zajęcia realizujące obecnie nową podstawę programową tak, aby w pełni wykorzystać potencjał rozwojowy dziecka. Do tego potrzebny jest kompetentny nauczyciel, który swoją wiedzą, doświadczeniem i zaangażowaniem będzie potrafił odpowiednio wdrożyć nowe technologie do procesu nauczania, zgodnie z założonymi celami. Nauczyciel, który w cyfrowym środowisku nie będzie czuć się pewnie i kompetentnie, może wycofywać się do sprawdzonych przez siebie starych metod nauczania, coraz bardziej odbiegających od zmieniającej się rzeczywistości. Proces wprowadzania zmian już się rozpoczął, dlatego ważne jest, aby pamiętać, że nowe technologie są świetnym narzędziem służącym realizacji wyznaczonych wcześniej celów edukacyjnych, przy jednoczesnym wspomaganiu rozwoju dziecka. Korzystanie z nich nie powinno być jednak celem samym w sobie - mają wspierać ucznia w jego dochodzeniu do wiedzy, bo to człowiek jest zawsze postawiony w centrum. Wśród warunków niezbędnych do prawidłowego wykorzystywania mediów cyfrowych w edukacji wczesnoszkolnej są zarówno cechy indywidualne nauczyciela (osobowościowe), posiadany przez niego zestaw cyfrowych kompetencji (nabytych np. $\mathrm{w}$ toku edukacji), wyposażenie $\mathrm{w}$ nowe technologie szkoły, jak i motywacja zewnętrzna $\mathrm{w}$ podnoszeniu kompetencji cyfrowych (awans zawodowy i podstawa programowa). Najważniejsza jednak jest motywacja wewnętrzna, dzięki której nauczyciel będzie wiarygodny dla swoich uczniów, zaangażowany i przekonany, że to co robi w obszarze mediów cyfrowych, przyniesie wymierne korzyści uczniom w ich zawodowej przyszłości. 


\section{BIBLIOGRAFIA}

Bednarek J., Multimedia w ksztatceniu, Wydawnictwo Naukowe PWN, Warszawa 2012.

Hoskins Sakamoto B., The role of technology in early years language education, [w:] Early Second Language Education: International perspectives of theory and practice, red. S. Mourano, M. Lourenco, Routledge, New York 2015.

Iwanicka A., Walter N., Kiełkiewicz-Janowiak A., Media and Information Literacy Policies in Poland (2013), ANR TRANSLIT and COST „TransformingAudiences/Transforming Societies", 2014, http://ppemi.enscachan.fr/data/media/colloque140528/rapports/ POLAND_2014.pdf.

Levinson P., Nowe nowe media, Wydawnictwo WAM, Kraków 2010.

Murawska-Najmiec E., Organizacje międzynarodowe: Edukacja medialna w polityce Unii Europejskiej i Unesco, [w:] Cyfrowa Przyszłość, 2016 https://nowoczesnapolska.org.pl/ wp-content/uploads/2012/01/Cyfrowa-Przysz \% C5\% 82o\% C5\% 9B\% C4\% 87-rozdzia\%C5\%82-06.pdf.

Ogonowska A., Ptaszek G., Edukacja medialna w dobie wspótczesnych zmian kulturowych, spotecznych i technologicznych, Oficyna Wydawnicza Impuls, Kraków 2015.

Polskaszkoław dobie cyfryzacji. Diagnoza 2017, red.M.Plebańska, Warszawa 2017, https:/ / onedrive.live.com/ ?authkey=\%21AOQ4UX8Db5IZqrw\&cid=3D4AC758B37A833C\&id=3D4AC758B37A833C\% 21108\&parId=root\&action=locate.

Pyżalski J., Dzieci w wieku przedszkolnym w świecie technologii informacyjno-komunikacyjnych - w stronę zagrożeń, [w:] Małe dzieci w świecie technologii informacyjno-komunikacyjnych. Pomiędzy utopijnymi szansami a przesadzonymi nadziejami, red. J. Pyżalski, Wydawnictwo „Eter”, Łódź 2017.

Pyżalski i in., Polskie badania EU Kids Online 2018, Wydawnictwo Naukowe UAM, Poznań 2019.

Pyżalski i in., Pozytywny internet i jego młodzi twórcy. Dobre i złe wiadomości z badań jakościowych, NASK, 2019,

Raport ICILS: Międzynarodowe Badanie Kompetencji Komputerowych i Informacyjnych, 2013, http:/ / eduentuzjasci.pl/ude/25-informacje/wydarzenia/1136-wyniki-miedzynarodowego-badania-kompetencji-komputerowych-i-informacyjnych-icils.html.

Rozporządzenie MEN z 14 lutego 2017 r., w sprawie Podstawy Programowej Kształcenia Ogólnego dla Szkół Podstawowych, DzU 2017, poz. 356, 1574.

Rozporządzenie MEN z 26 lipca 2018 r. w sprawie uzyskiwania stopni awansu zawodowego przez nauczycieli, §12 ust. 1.

Tanaś M., Raport z Badania Nastolatki 3.0. NASK, Warszawa 2017. 